Bangl. J. Vet. Med. (2009). 7 (1) : 239 - 247

\title{
RETROSPECTIVE STUDY OF SOME POULTRY DISEASES AT GAIBANDHA DISTRICT IN BANGLADESH
}

\author{
A. Islam*1, A. A. Trisha ${ }^{2}$, M. Das ${ }^{3}$ and M. R. Amin ${ }^{4}$ \\ ${ }^{1}$ REAP Program, Mennonite Central Committee, Bangladesh; ${ }^{2}$ Livestock Training Institute, Gaibandha, ${ }^{3}$ Bay \\ Agro Industries Ltd. Dhaka-215, Bangladesh; ${ }^{4}$ Field Disease Investigation Laboratory, Gaibandha, Bangladesh
}

\begin{abstract}
A total of 325 chickens, duck and pigeon, dead or sick, brought for diagnosis to the FDIL (field disease investigation laboratory), Guibandha during the period from July, 2005 to June, 2006 were taken into consideration in this study to know the seasonal occurrence of diseases and their comparison and to identify the effect of season and age for developing the diseases. Among the examined birds 251 were chicken including local and commercial birds, 67 were ducks and 7 were pigeon. The diagnosed diseases were parasitic diseases including coccidiosis, ascaridiosis and schistosomiasis; viral diseases including new castle disease (ND), infectious bursal disease (IBD), avian leucosis (AL) and duck plague (DP), bacterial diseases including salmonellosis, pasteurellosis and colibacillosis, non-infectious diseases including ascites, egg bound, cannibalism and fatty liver hemorrhagic disease, MC complex (mycoplasmosis-colibacillosis complex) and fungal infection including aspergillosis. The occurrence of parasitic diseases $(86.2 \%)$ was the highest, followed by viral diseases $(32.6 \%)$, bacterial diseases $(25.8 \%)$ and non-infectious diseases $(12.9 \%)$. In chickens the occurrence of parasitic diseases was the highest $(88.4 \%)$ followed by bacterial diseases $(28.3 \%)$, viral diseases $(27.1 \%)$, non-infectious diseases $(16.30 \%)$, MC complex $(3.6 \%)$ and aspergillosis $(1.6 \%)$. Bacterial diseases were significantly $(p<0.05)$ higher in winter as well as in rainy season compared to summer season. Occurrence of pasteurellosis was significantly $(p<0.05)$ higher in winter $(p<0.05)$ and rainy $(p<0.01)$ season compared to summer season. Parasitic diseases were significantly $(p<0.01)$ higher in winter $(97.2 \%)$ compared to summer $(83.3 \%)$. The occurrence of coccidiosis was $88 \%$ and it was significantly $(p<0.01)$ higher in winter $(97.2 \%)$ compared to summer $(82.2 \%)$. Egg bound was present among $10 \%$ birds and it was significantly $(p<0.05)$ lower in rainy season compared to summer season. In case of ducks the presence of parasitic diseases was the highest $(77.60 \%)$ followed by viral diseases $(56.7 \%)$, bacterial diseases $(16.40 \%)$ and non-infectious diseases (1.50\%). Duck plague was present in $56.7 \%$ birds and it was significantly $(p<0.05)$ higher in winter $(80 \%)$ season compared to summer $(44.8 \%)$ season. The occurrence of duck plague was observed in $56.70 \%$ birds and it was significantly $(p<0.05)$ higher in laying stage $(67.60 \%)$ than pullet stage $(43.30 \%)$. Incase of pigeon $28.60 \%$ birds showed bacterial infections and $85.70 \%$ birds showed parasitic infestations. Present study suggests that various infectious and non-infectious diseases are prevalent among the poultry of Guibandha district. So effective control measures should be taken to minimize this problem.
\end{abstract}

Key words: Poultry, diseases, multivariable logistic regression model, Z-test

INTRODUCTION

People of Bangladesh traditionally rear local chicken, duck and pigeon either in semi-scavenging or in scavenging system to minimize the need of protein. Poultry rearing is one of the most important sources of income for rural women especially for landless and marginal farmers (Paul et al., 1990). From last few years commercial poultry farming has been developed where some high yielding strains of chicken are reared in intensive system. The total number of domestic chicken in our country is about 195 million (Dolberg, 2008). The approximate number of ducks in our country is about 38.1 millions and $89 \%$ of those are reared in semiscavenging system (Dolberg, 2008). Though pigeon rearing is popular in rural areas of Bangladesh but there is no definite statistics of pigeon population in Bangladesh (Nasrin, 2004). In spite of prevailing favorable agro-climatic conditions, the booming poultry industry is witnessing a series of problems due to recent spurt in various infectious and noninfectious diseases. Thus economy of the poultry farm depends on the percentage of mortality of birds which is mainly caused by various infectious and non-infectious diseases (Giasuddin et al., 2002) in our country. Due to different diseases, 30\% chicken mortality occurs in our country annually (Ali, 1994). Increased duck mortality due to infectious diseases such as duck plague and duck cholera is common in our country (Baki et al., 1986). Local chicken, ducks and pigeon are reared in semi-scavenging or scavenging system in our country. Such birds are in constant contact with soil (Pandey and Jiang, 1992), which serves as an important reservoir and transmission site for external larval stages of helminthes and insects (Muhairwa et al., 2007). For this reason, all free-range managed local birds more susceptible to helminthiasis compared to commercially reared birds. Especially in free-range birds parasitic infestations are often neglected (Pandey and Jiang, 1992) though they are causing reduced growth and mortality (Muhairwa et al., 2007).

*Corresponding author's e-mail address: islam_ausraf@yahoo.com

Copyright (c) 2009 Bangladesh Society for Veterinary Medicine

All rights reserved 1729-7893/0173/09 


\section{A. Islam and others}

Rabbi et al. (2006) reporded that $100 \%$ local chicken, $48.75 \%$ layers and $3.75 \%$ broilers were suffering from helminthiasis. Strategic control program can check this great economic loss due to various diseases. For any control program the primary requirement is to know the epidemiological pattern of the causal agent of the disease. An epidemiological pattern can be developed by a timely and accurate diagnosis by which tools for a strategic control programme can be selected. But in our country, lack of veterinary diagnostic centre sometime makes the diagnosis of disease difficult. The Field Disease Investigation Laboratories (FDIL) is government organizations, involved in diagnosis of livestock diseases in grass-root levels. So, we have made an attempt to find out the prevalence of different diseases with seasonal dynamics and to identify the significant risk factors for poultry diseases in the areas under the jurisdiction of FDIL, Guibandha, based on the results of post-mortem examinations over a period from July, 2005 to June, 2006.

\section{MATERIALS AND METHODS}

A total of 325 poultry, duck and pigeon were examined through post mortem at FDIL, Guibandha during the period from July, 2005 to June, 2006. Of the examined birds 251 were chickens, 67 were ducks and 7 were pigeon.

\section{Examination of birds}

Before clinical examination, age, species and breed of the birds and other relevant data were recorded. Here chickens include commercial and local scavenging birds. For the convenience of the study, ducks were divided into two age groups: pullet stage (up to 140 days) and laying stage (more than 140 days). Research period was divided into 3 seasons such as rainy (July to October), summer (March to June) and winter (November to February). Diagnosis of different diseases was made considering the history of the flock, age of the affected birds, clinical signs and postmortem lesions. Age related prevalences were calculated only for ducks. Incase of chicken, these prevalences were not computed as the time of maturity of layers, broilers and scavenging poultry were different.

\section{Statistical analysis}

The chi-square tests were performed to know the significance of the associations between the prevalences of the diseases in poultry (Everitt, 1992). Disease prevalences were compared by Z-test (normal test) only for significant association (Zar, 2002). Two multivariable logistic regression models were fitted for identifying effect of season and age that significantly influences the prevalence of disease in poultry (Hosmer and Lemeshow, 1989).

\section{RESULTS AND DISCUSSION}

\section{Seasonal occurrence of diseases in chickens}

A total of 251 chickens including layers, broilers and local scavenging birds were examined throughout the year. Among them 90 birds were examined in summer, 71 in winter and 90 in rainy season (Table 1). Bacterial diseases were observed in $28.3 \%$ chickens. The highest occurrence was found in winter season (33.8\%) followed by rainy $(33.3 \%)$ and summer $(18.9 \%)$ season. These diseases had significant $(p<0.05)$ association with season and were significantly $(p<0.05)$ higher in winter as well as in rainy season compared to summer season. This finding were was in agreement with Rimler and Glisson (1997). Three types of bacterial diseases were observed in chickens such as salmonellosis, pasteurellosis and colibacillosis (fig. 1). Among these diseases the occurrence of colibacillosis was the highest (17.1\%) and this disease was the most frequent in winter season (25.4\%) compared to other two seasons. This finding did not match with Mushi et al., (2008) and Nicole et al., (2000) who found the highest occurrence of the disease during the rainy season. There are some factors which make the birds more susceptible such as presence of ammonia, dust in poultry house, over-stocking, poor hygienic management, high temperature of the shed etc (Barnes and Gross, 1997). These factors are more prominent during the winter seasons compared to other two seasons in our country. May be for this reason the result varied with others. Highest occurrence of salmonellosis $(10 \%)$ and pasteurellosis $(8.9 \%)$ was observed in rainy season. Nearly similar result was observed by Kutubuddin (1973) who reported $12 \%$ cases of salmonellosis and $10.66 \%$ cases of pasteurellosis in his study. Occurrence of pasteurellosis was significantly $(p<0.05)$ associated with season and was significantly higher in winter $(p<0.05)$ and rainy $(p<0.01)$ season compared to summer season. It is evident from Table 5 that in winter season, a bird had 4.528 times and in rainy season 7.714 times more possibility of being infected than that of summer season by pasteurellosis. This finding was in agreement with that of Rimler and Glisson (1997) and Thitisak (1992) but did not match with Islam et al. (2003) and Giasuddin et al. (2002). 
Retrospective study of poultry diseases in Bangladesh

Viral diseases were found in $27.1 \%$ birds. Highest episode of viral diseases was observed in summer (30\%) followed by winter (26.8\%) and rainy (24.4\%) season. The observed viral diseases were new castle disease (ND), infectious bursal disease (IBD) (fig. 2, 3 and 4) and avian leucosis (AL). IBD was the most frequent (24.9\%) and its highest occurrence was observed in summer (22.2\%) and rainy (22.2\%) season.

Table 1. Seasonal occurrence of diseases in chicken

\begin{tabular}{|c|c|c|c|c|c|c|c|}
\hline \multirow[t]{2}{*}{ Diseases } & \multicolumn{3}{|l|}{ Season } & \multirow[t]{2}{*}{$\begin{array}{l}\text { Total } \\
(\mathrm{N}=251)\end{array}$} & \multirow[t]{2}{*}{$\begin{array}{l}\text { P-value } \\
\text { of } \chi^{2} \text { test }^{\mathrm{a}}\end{array}$} & \multicolumn{2}{|c|}{$\begin{array}{l}\text { P-value of Z } \\
\text { test }^{b}\end{array}$} \\
\hline & $\begin{array}{l}\text { Summer } \\
(\mathrm{n}=90)\end{array}$ & $\begin{array}{l}\text { Winter } \\
(\mathrm{n}=71)\end{array}$ & $\begin{array}{l}\text { Rainy } \\
(n=90)\end{array}$ & & & Winter & Rainy \\
\hline Bacterial diseases & $17(18.9 \%)$ & $24(33.8 \%)$ & $30(33.3 \%)$ & $71(28.3 \%)$ & 0.047 & & \\
\hline Salmonellosis & $6(6.7 \%)$ & $2(2.8 \%)$ & $9(10.0 \%)$ & $17(6.8 \%)$ & 0.197 & & \\
\hline Pasteurellosis & 0 & $4(5.6 \%)$ & $8(8.9 \%)$ & $12(4.8 \%)$ & 0.019 & 0.0113 & 0.0014 \\
\hline Colibacillosis & $12(13.3 \%)$ & $18(25.4 \%)$ & $13(14.4 \%)$ & $43(17.1 \%)$ & 0.093 & & \\
\hline Viral diseases & $27(30.0 \%)$ & $19(26.8 \%)$ & $22(24.4 \%)$ & $68(27.1 \%)$ & 0.702 & & \\
\hline Newcastle Disease & $6(6.7 \%)$ & $4(5.6 \%)$ & $2(2.2 \%)$ & $12(4.8 \%)$ & 0.348 & & \\
\hline IBD & $20(22.2 \%)$ & $15(21.1 \%)$ & $20(22.2 \%)$ & $55(21.9 \%)$ & 0.982 & & \\
\hline Avian leukosis & $1(1.1 \%)$ & 0 & 0 & $1(0.4 \%)$ & 0.407 & & \\
\hline Parasitic diseases & $75(83.3 \%)$ & $69(97.2 \%)$ & $78(86.7 \%)$ & $222(88.4 \%)$ & 0.019 & 0.0023 & 0.2676 \\
\hline Coccidiosis & $74(82.2 \%)$ & $69(97.2 \%)$ & $78(86.7 \%)$ & $221(88 \%)$ & 0.013 & 0.0014 & 0.2061 \\
\hline Ascaridiosis & $1(1.1 \%)$ & $1(1.4 \%)$ & 0 & $2(0.8 \%)$ & 0.557 & & \\
\hline MC complex & $2(2.2 \%)$ & $5(7 \%)$ & $2(2.2 \%)$ & $9(3.6 \%)$ & 0.181 & & \\
\hline Aspergillosis & $4(4.4 \%)$ & 0 & 0 & $4(1.6 \%)$ & 0.026 & 0.0014 & 0.0217 \\
\hline Non-infectious diseases & $19(21.1 \%)$ & $13(18.3 \%)$ & $9(10.0 \%)$ & $41(16.3 \%)$ & 0.114 & & \\
\hline Ascites & $2(2.2 \%)$ & $5(7 \%)$ & $5(5.6 \%)$ & $12(4.8 \%)$ & 0.331 & & \\
\hline Egg bound & $14(15.6 \%)$ & $7(9.9 \%)$ & $4(4.4 \%)$ & $25(10 \%)$ & 0.045 & 0.1446 & 0.0207 \\
\hline Cannibalism & $4(4.4 \%)$ & $2(2.8 \%)$ & 0 & $6(2.4 \%)$ & 0.143 & & \\
\hline Fatty liver hemorrhag & $2(2.2 \%)$ & 0 & 0 & $2(0.8 \%)$ & 0.165 & & \\
\hline
\end{tabular}

disease syndrome

${ }^{\mathrm{a}} p$-value $<0.05$ and $p$-value $<0.01$ indicate significant at $5 \%$ and $1 \%$ level respectively; ${ }^{\mathrm{b}} \mathrm{Z}$ tests were performed for comparing the prevalences of winter and rainy with that of summer

Table 2. Seasonal occurrence of diseases in ducks

\begin{tabular}{|c|c|c|c|c|c|c|c|}
\hline \multirow[t]{2}{*}{ Diseases } & \multicolumn{3}{|l|}{ Season } & \multirow{2}{*}{$\begin{array}{l}\text { Total } \\
(\mathrm{N}=67)\end{array}$} & \multirow{2}{*}{$\begin{array}{l}\text { P-value } \\
\text { of } \chi^{2} \text { test }^{\text {a }}\end{array}$} & \multicolumn{2}{|c|}{$\mathrm{P}$-value of $\mathrm{Z}$ test $\mathrm{t}^{\mathrm{b}}$} \\
\hline & $\begin{array}{l}\text { Summer } \\
(\mathrm{n}=29)\end{array}$ & $\begin{array}{l}\text { Winter } \\
(\mathrm{n}=20)\end{array}$ & $\begin{array}{l}\text { Rainy } \\
(\mathrm{n}=18)\end{array}$ & & & Winter & Rainy \\
\hline Bacterial diseases & $5(17.2 \%)$ & $2(10.0 \%)$ & $4(22.2 \%)$ & $11(16.4 \%)$ & 0.590 & & \\
\hline Salmonellosis & $1(3.4 \%)$ & 0 & 0 & $1(1.5 \%)$ & 0.514 & & \\
\hline Pasteurellosis & $3(10.3 \%)$ & $2(10.0 \%)$ & $4(22.2 \%)$ & $9(13.4 \%)$ & 0.441 & & \\
\hline Colibacillosis & $1(3.4 \%)$ & 0 & 0 & $1(1.5 \%)$ & 0.514 & & \\
\hline Viral diseases & $13(44.8 \%)$ & $16(80.0 \%)$ & $9(50.0 \%)$ & $38(56.7 \%)$ & 0.040 & 0.0069 & 0.3369 \\
\hline Duck Plague & $13(44.8 \%)$ & $16(80.0 \%)$ & $9(50.0 \%)$ & $38(56.7 \%)$ & 0.040 & 0.0069 & 0.3369 \\
\hline Parasitic diseases & $24(82.8 \%)$ & $15(75.0 \%)$ & $13(72.2 \%)$ & $52(77.6 \%)$ & 0.663 & & \\
\hline Coccidiosis & $24(82.8 \%)$ & $14(70.0 \%)$ & $13(72.2 \%)$ & $51(76.1 \%)$ & 0.531 & & \\
\hline Schistosomiasis & $1(3.4 \%)$ & $1(5.0 \%)$ & $1(5.6 \%)$ & $3(4.5 \%)$ & 0.935 & & \\
\hline Non-infectious diseases & $1(3.4 \%)$ & 0 & 0 & $1(1.5 \%)$ & 0.514 & & \\
\hline Egg bound & $1(3.4 \%)$ & 0 & 0 & $1(1.5 \%)$ & 0.514 & & \\
\hline
\end{tabular}




\section{A. Islam and others}

This result was similar with that of Islam et al. (2003) who reported $24.26 \%$ cases of IBD in their study. Bhattacharjee et al. (1996), Islam et al. (1988) and Talha et al. (2001) reported 10.99\%, 16\% and $19.16 \%$ cases of IBD respectively in their study. Giasuddin et al. (2002) detected $11.80 \%$ positive cases of IBD in their study. The occurrence of $\mathrm{AL}$ was the lowest $(0.4 \%)$ and it existed only in summer season (1.1\%). ND was found among $4.8 \%$ birds and occurrence was the highest in summer season (6.7\%). But Talha et al. (2001) and Islam et al. (1988) found $10.24 \%$ and $17.20 \%$ cases of ND respectively in their study. Islam et al. (2003) reported $6.73 \%$ cases of ND in their study. Giasuddin et al. (2002) observed $7.50 \%$ occurrence of the same disease in their study. Variation between past and present study may be due to more easily available vaccine that caused reduced occurrence of ND.

Table 3. Age related occurrence of diseases in ducks

\begin{tabular}{|c|c|c|c|c|}
\hline \multirow[t]{2}{*}{ Diseases } & \multicolumn{2}{|l|}{ Age } & \multirow{2}{*}{$\begin{array}{l}\text { Total } \\
(\mathrm{N}=67)\end{array}$} & \multirow{2}{*}{$\begin{array}{l}\text { P-value of } \chi^{2} \\
\text { test }\end{array}$} \\
\hline & $\begin{array}{l}\text { Pullet stage } \\
(\mathrm{n}=30)\end{array}$ & $\begin{array}{l}\text { Laying stage } \\
(\mathrm{n}=37)\end{array}$ & & \\
\hline Bacterial diseases & $7(23.3 \%)$ & $4(10.8 \%)$ & $11(16.4 \%)$ & 0.169 \\
\hline Salmonellosis & $1(3.3 \%)$ & 0 & $1(1.5 \%)$ & 0.916 \\
\hline Pasteurellosis & $5(16.7 \%)$ & $4(10.8 \%)$ & $9(13.4 \%)$ & 0.735 \\
\hline Colibacillosis & $1(3.3 \%)$ & 0 & $1(1.5 \%)$ & 0.916 \\
\hline Viral diseases & $13(43.3 \%)$ & $25(67.6 \%)$ & $38(56.7 \%)$ & 0.046 \\
\hline Duck Plague & $13(43.3 \%)$ & $25(67.6 \%)$ & $38(56.7 \%)$ & 0.046 \\
\hline Parasitic diseases & $23(76.7 \%)$ & $29(78.4 \%)$ & $52(77.6 \%)$ & 0.867 \\
\hline Coccidiosis & $23(76.7 \%)$ & $28(75.7 \%)$ & $51(76.1 \%)$ & 0.925 \\
\hline Schistosomiasis & $2(6.7 \%)$ & $1(2.7 \%)$ & $3(4.5 \%)$ & 0.435 \\
\hline Non- infectious diseases & 0 & $1(2.7 \%)$ & $1(1.5 \%)$ & 1 \\
\hline Egg bound & 0 & $1(2.7 \%)$ & $1(1.5 \%)$ & 1 \\
\hline
\end{tabular}

${ }^{\mathrm{a} p}$-value $<0.05$ indicates significant at $5 \%$ level.

Among all the diseases the occurrence of parasitic diseases was the highest $(88.4 \%)$. These diseases were significantly $(p<0.05)$ associated with the season and were significantly $(p<0.01)$ higher in winter $(97.2 \%)$ compared to summer season $(83.3 \%)$. Two types of parasitic diseases were observed: coccidiosis (Fig. 5) and ascaridiosis. The occurrence of coccidiosis was the highest $(88 \%)$ and significantly $(p<0.05)$ associated with season.

Table 4. Seasonal occurrence of diseases in pigeon

\begin{tabular}{lllll}
\hline Diseases & Season & & \multicolumn{2}{l}{ Total $(\mathrm{N}=7)$} \\
\cline { 2 - 4 } & Summer $(\mathrm{n}=3)$ & Winter $(\mathrm{n}=3)$ & Rainy $(\mathrm{n}=1)$ & \\
\hline Bacterial diseases & 0 & $1(33.3 \%)$ & $1(100 \%)$ & $2(28.6 \%)$ \\
\hline \hline Pasteurellosis & 0 & $1(33.3 \%)$ & 0 & $1(14.3 \%)$ \\
\hline Colibacillosis & 0 & 0 & $1(100.0 \%)$ & $1(14.3 \%)$ \\
\hline Parasitic diseases & $3(100.0 \%)$ & $3(100.0 \%)$ & 0 & $6(85.7 \%)$ \\
\hline Coccidiosis & $3(100.0 \%)$ & $3(100.0 \%)$ & 0 & $6(85.7 \%)$ \\
\hline Ascaridiosis & $1(33.3 \%)$ & 0 & 0 & $1(14.3 \%)$ \\
\hline
\end{tabular}

The episode of coccidiosis was significantly $(p<0.01)$ higher in winter $(97.2 \%)$ compared to summer $(82.2 \%)$. Giasuddin et al. (2002) and Islam et al. (2003) reported 3.87\% and 9.46\% occurrence of coccidiosis in their study respectively. Variation may be due to the poor management system of the study area. Coccidiosis becomes important as a disease where birds are reared in litter systems that provide favorable conditions for the development of the oocysts (Hofstad et al., 1978). Young birds pick up the infection from contaminated premises 
Retrospective study of poultry diseases in Bangladesh

that may have been contaminated previously by other young infected birds or by adult birds. Oocysts remain viable in litter for many months and this way they can contaminate a farm from year to year (Stayer et al., 1995). May be due to less frequent changing of litter and providing more temperature caused higher occurrence of the disease in the winter season. The occurrence of ascaridiosis was very minimum $(0.8 \%)$ and it was present only in summer $(1.1 \%)$ and winter $(1.4 \%)$ seasons.

Table 5. Identification of effect of season and age for diseases

\begin{tabular}{llllllll}
\hline Model $^{\mathrm{a}}$ & Variable & Category & Coefficient & S. E. (b) & Wald's P & OR & $95 \%$ CI \\
\hline 1 & Age & & $-.032^{* *}$ & 0.011 & 0.005 & 0.969 & $0.947-0.991$ \\
\hline 2 & Season & Summer & & & & & \\
& & Winter & $1.510^{*}$ & 0.750 & 0.044 & 4.528 & $1.042-19.674$ \\
& & Rainy & $2.043^{* *}$ & 0.720 & 0.005 & 7.714 & $1.882-31.611$ \\
\hline 3 & Season & Summer & & & & & \\
& & Winter & $1.814^{* *}$ & 0.707 & 0.010 & 6.138 & $1.535-24.548$ \\
& & Rainy & 0.285 & 0.630 & 0.651 & 1.329 & $0.387-4.566$ \\
\hline 4 & Age & & $0.007^{* *}$ & 0.002 & 0.003 & 1.007 & $1.002-1.012$ \\
\hline
\end{tabular}

${ }^{a}$ Model 1, 2, 3 and 4 were only significant when they were successively fitted for the diseases colibacillosis, pasteurellosis, duck plague and egg bound; ${ }^{*}$ and ${ }^{* *}$ indicate significant at $1 \%$ and $5 \%$ levels of probability respectively; ${ }^{\mathrm{c}}$ indicates reference category.

The occurrence of MC complex (Fig. 6) was only observed in 3.6\% birds. Somewhat greater occurrence $(5.32 \%)$ was described by Islam et al. (2003). Talha et al. (2001) reported a higher occurrence of mycoplasmosis $(11.55 \%)$ in Mymensingh region.

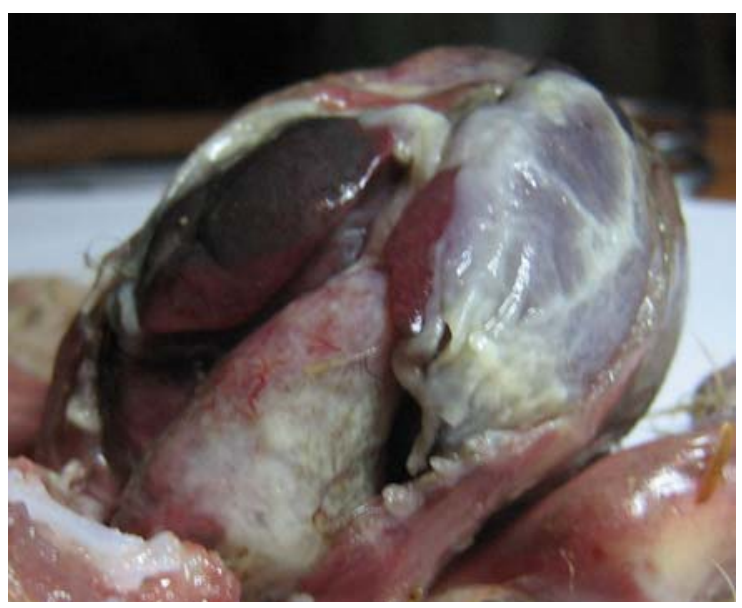

Fig.1. Colibacillosis in chicken showing covering on heart and liver

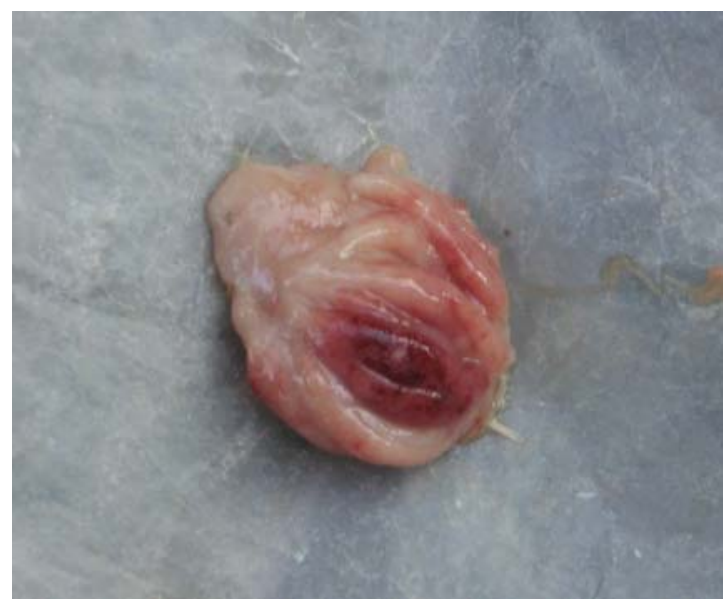

Fig. 2. Swollen bursa of a chick infected with IBD 


\section{A. Islam and others}

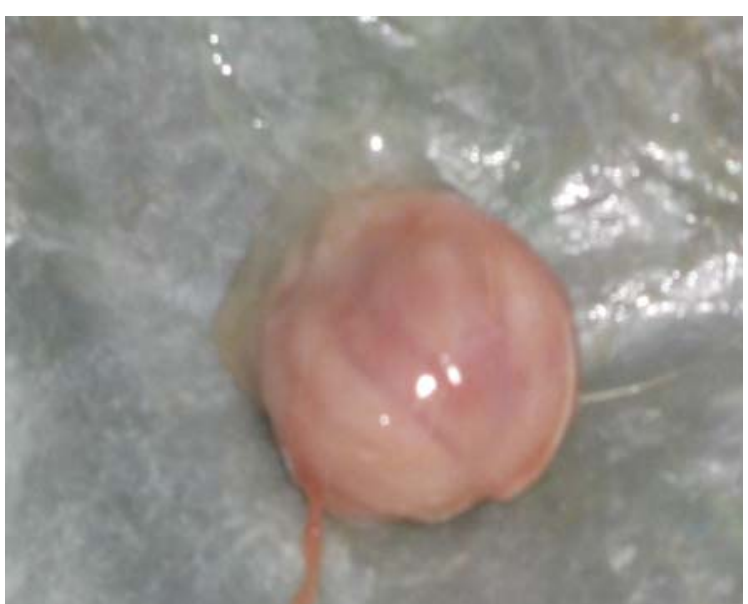

Fig.3. Swollen bursa of a chick infected with IBD

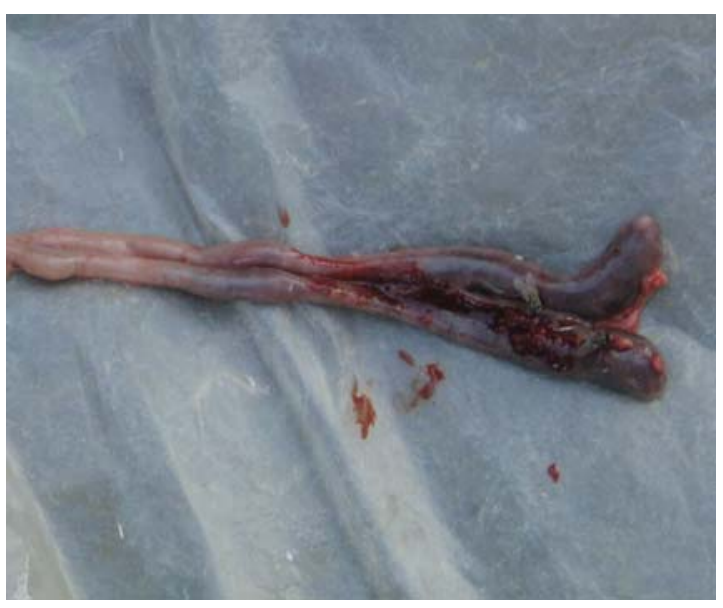

Fig.5. Chicken coccidiosis showing haemorrhage in caecum

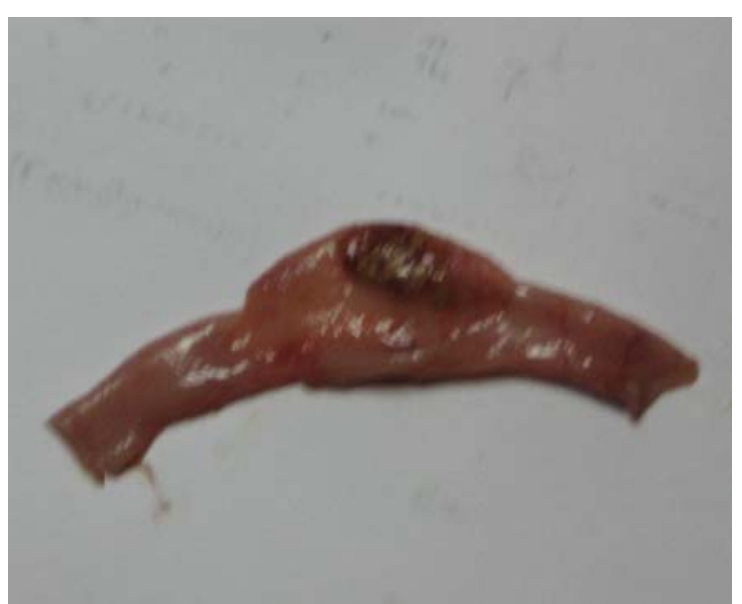

Fig.4. Intestinal plaque of a chick infected with IBD

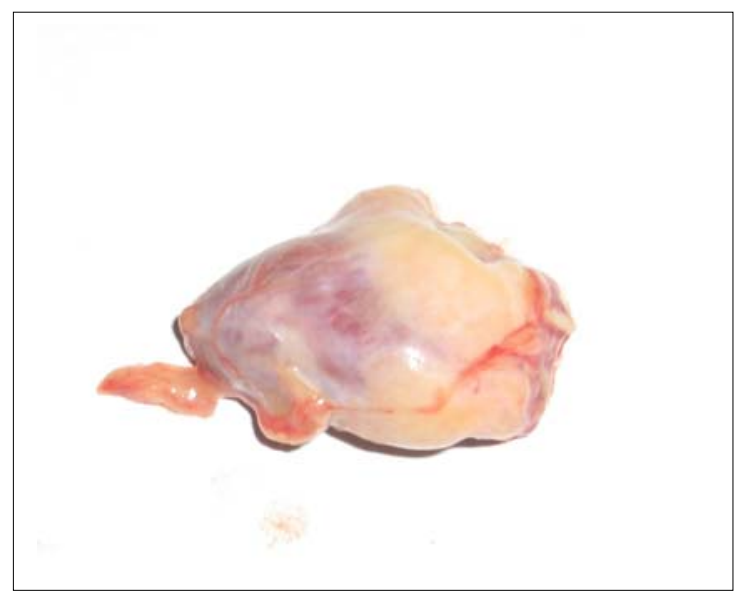

Fig.6. Chicken MC Complex showing covering on heart 
Aspergillosis was observed only in summer season and $1.6 \%$ birds were infected with this disease. In the summer season there is both strong sunlight and heavy rainfall causing an altering condition that provides an ideal situation for aspergillosis (Anon, 1997). Talha et al. (2001) reported 4.20\% positive cases in Mymensingh. On the other hand, Islam et al. (2003) reported $17.53 \%$ positive cases. Giasuddin et al. (2002) reported 8.11\% presence of the disease in their study. In this study, $16.30 \%$ birds were suffering from non-infectious diseases. Lower number of positive cases of the same disease was also observed by Giasuddin et al. (2002) and Talha et al. (2001) who recorded $12.40 \%$ and $9 \%$ positive cases respectively from their investigations. Highest episode was observed in summer $(21.10 \%)$ followed by winter $(18.30 \%)$ and rainy $(10 \%)$ season. Four non-infectious diseases were recorded such as ascites, egg bound, cannibalism and fatty liver hemorrhagic disease. Maximum number of birds was suffering from egg bound $(10 \%)$ and it had significant $(p<0.05)$ association with season. In rainy season its presence was significantly $(p<0.05)$ lower than summer season. This finding could not be discussed due to paucity of literatures. On the other hand, $4.8 \%$ birds were suffering from ascites, $2.40 \%$ from cannibalism and only $0.80 \%$ from fatty liver hemorrhagic disease syndrome. Cannibalism was absent in winter season. Highest occurrence of ascites $(7 \%)$ was detected in winter and that of cannibalism $(4.40 \%)$ in summer. Fatty liver hemorrhagic disease $(2.20 \%)$ was present only in summer. Because outbreaks of this disease are most common in high producing flocks during hot weather (Anon, 1997) (Table 1).

\section{Seasonal occurrence of diseases in ducks}

A total of 67 ducks were examined throughout the year. Among them 29 were examined in summer, 20 in winter and 18 in rainy season (Table 2).

The occurrence of bacterial diseases was observed in $16.40 \%$ ducks and it was the highest in rainy $(22.20 \%)$ followed by summer (17.20\%) and winter (10\%) season. Nearly similar result was observed by Das et al. (2007) who found $15.61 \%$ bacterial infections in their study. Ducks were infected with 3 types of bacterial diseases such as salmonellosis, pasteurellosis and colibacillosis. Among these diseases occurrene of pasteurellosis $(13.40 \%)$ was the highest and its highest occurrence was observed in rainy $(22.20 \%)$ season followed by summer $(10.30 \%)$ and winter $(10 \%)$ season. Salmonellosis $(3.40 \%)$ and colibacillosis $(3.40 \%)$ was present only in summer season. Das et al. (2007) found 5.37\% salmonellosis and 4.39\% colibacillosis in their study. Tran et al. (2004) and Das et al. (2005) reported salmonellosis in $20 \%$ and $14 \%$ ducks respectively.

Only one viral disease was observed and it was duck plague. Duck plague was present in $56.7 \%$ ducks and its occurrence was significantly $(p<0.05)$ associated with season. Occurrence of this disease was significantly $(p<0.05)$ higher in winter $(80 \%)$ season compared to summer $(44.8 \%)$ season. It is evident from Table 5 that in winter season, a bird had 6.138 times more possibility of being infected than that of summer season by the disease duck plague. May be due to cold stress the disease became more dominant during the winter season. Das et al. (2007) detected duck plague among $5.37 \%$ birds in their study. This difference may be due to the lack of vaccination in the study area, as the vaccine is not easily available throughout the country.

Among all the observed diseases the occurrence of parasitic diseases was the highest (77.60\%). Farjana et al. (2004) found $96.99 \%$ positive cases of parasitic diseases of ducks in their study at Netrokona district. Nearly similar result was obtained by Belokobilenko (1964), Ahmed (1969) and Baki and Mondal (1998) who reported $85.8 \%, 66 \%$ and $65.3 \%$ helminth infection in ducks respectively. The occurrence was the highest in summer $(82.80 \%)$ season followed by winter $(75 \%)$ and rainy $(72.23 \%)$ season. Coccidiosis and schistosomiasis were the two observed parasitic diseases. Coccidiosis was prevalent in $76.1 \%$ birds and its presence was the highest in summer $(82.80 \%)$ season followed by rainy $(72.20 \%)$ and winter $(70 \%)$ season. Though incase of chickens the episode of coccidiosis was the highest in winter, incase of ducks the highest occurrence was observed in summer. This variation may be due the intensive rearing system of broiler and layers. On the other hand, most of the ducks of our country are reared in semi-scavenging or scavenging system. Presence of schistosomiasis was much lower and it was present only in $4.50 \%$ birds. Only one non-infectious disease was observed and it was egg bound. It was found in only one duck (1.50\%) in summer season (Table 2$)$.

\section{Age related occurrence of diseases in ducks}

It is evident from the Table- 3 that bacterial diseases were present in $16.40 \%$ birds and it was insignificantly $(p>0.05)$ higher in pullet stage (23.30\%) than laying stage $(10.80 \%)$. Among the bacterial diseases the presence of pasteurellosis $(13.40 \%)$ was the highest and its presence was insignificantly $(p>0.05)$ higher in pullet stage $(16.70 \%)$ than laying stage $(10.80 \%)$. Salmonellosis $(3.30 \%)$ and colibacillosis $(3.30 \%)$ were present only in pullet stage. 


\section{A. Islam and others}

It is evident from Table 5 that age had a significant $(p<0.01)$ effect on the development of the disease colibacillosis. The negative sign of the coefficient indicates that age had a negative effect of the disease that a bird of higher age had more resistance than that of a bird of lower age. Colibacillosis is usually more frequent in young birds compared to mature birds (Anonymous, 1997). This finding was similar with that of Mushi et al., (2008).

Only one viral disease was diagnosed and it was duck plague. The presence of duck plague was observed in $56.70 \%$ birds. The occurrence of this disease was significantly $(p<0.05)$ higher in laying stage $(67.60 \%)$ than pullet stage $(43.30 \%)$. This finding could not be compared due to paucity of sufficient literatures.

Parasitic diseases were found among $77.6 \%$ ducks. Coccidiosis was present among $76.1 \%$ ducks and schistosomiasis among $4.5 \%$ ducks.

Egg bound was the only one observed non-infectious disease and its occurrence was $1.5 \%$. It is evident from Table 5 that age had a significant $(p<0.01)$ effect on the development of the disease egg bound. The positive sign of the coefficient indicates that age had a positive effect on the disease that a bird of higher age had more possibility of being infected than a bird of lower age. This disease occurs when a duck start laying eggs. For this reason, a bird of higher age had more possibility of being infected by the disease than a bird of lower age.

\section{Occurrence of diseases in pigeon}

Only 7 pigeons were examined throughout the year. Of them $28.60 \%$ birds showed bacterial infections among which pasteurellosis was found in $14.30 \%$ and colibacillosis in $14.30 \%$ birds. Parasitic diseases were observed in $85.70 \%$ birds (Table 4 ).

From the above study it can be concluded that the poultry of the study area are suffering from several diseases. These diseases are directly or indirectly causing economic losses of the farmers. So, it is essential to take attempt to control these diseases for the development of the poultry industry of the study area.

\section{REFERENCES}

1 Ahmed S (1969). Survey on type of helminthes commonly found in country ducks. Pakistan Journal of Veterinary Science. 3: 110-112.

2. Ali MJ (1994). Current status of veterinary biologics production in Bangladesh and their quality control. Proceedings of the BSVER symposium held on July 28, 1994 at NIPSOM auditorium, Mohakhali, Dhaka, Bangladesh. pp. 4-7.

3. Anonymous (1997). National Poultry Improvement Plan and Auxiliary Provisions. United States Development of Agriculture. Animal and Health Inspection Services, APHIS, 91-55-038.

4. Dolberg F (2008). Poultry Sector Country Review: Bangladesh. Prepared by FAO Animal Production and Health Division, Emergency Centre for Transboundary Animal Diseases Socioeconomics, Production and Biodiversity Unit. pp. 7.

5. Baki MA and Mondal MMH (1998). An investigation on the pathology of parasitic diseases of ducks in Bangladesh. Bangladesh Journal of Livestock. 5: 1-8.

6. Baki MA, Sarker AJ and Mondal MMH (1986). Pathological investigation on the mortality of ducks in Bangladesh. BAU Research Proceedings. 1: 328-341.

7. Barnes HJ and Gross WB (1997). Colibacillosis. In: Barnes HJ et al. (Eds). Diseases of Poultry. 10 ${ }^{\text {th }}$ Edn. Iowa State University Press. pp: 131-141.

8. Belokobilenko VT (1964). Helminths and helminthiases of poultry in South Easterb Kazakh SSR. In: Helminths and helminthiases of poultry in Kazakhstan. Alma-Ata: Izdat Akad Nuak Kazakhstanskoi SSR. Helminthological Abstract. pp. 17.

9. Bhattacharjee PS, Kundu, RL, Bisws RK, Majumder JU, Hossain E and Miah AH (1996). A retrospective analysis of chicken diseases diagnosed at the Central Disease Investigation Laboratory, Dhaka. Bangladesh Veterinary Journal. 30: 105-113.

10. Das PM, Anisuzzaman and Tarannum SS (2007). Proportionate incidence of diseases of ducks in some districts of Bangladesh. $5^{\text {th }}$ International Poultry Show and Seminar, World' Poultry Science Association, Bangladesh Branch, 1-3 March 2007, Dhaka, Bangladesh. pp. 196-202.

11. Das PM, Rajib DMM, Monira N and Islam MR (2005). A retrospective analysis on the proportional incidence of poultry diseases in greater Mymensingh district of Bangladesh. Proceedings of the Seminar. $4^{\text {th }}$ International Poultry Show and Seminar 2005, 10-12 March, Bangladesh China Friendship Conference Centre, Dhaka, Bangladesh, World' Poultry Science Association, Bangladesh Branch. pp. 33-37.

12. Everitt BS (1992). The Analysis of Contingency tables. $2^{\text {nd }}$ edn. Chapman and Hall, London. pp. 11-19.

13. Farjana T, Alim MA, Das PM and Mondal MMH (2004). Helminth infection in ducks at free-range and semi-intensive farming in two districts of Bangladesh. Bangladesh Veterinary Journal. 38(3-4): 125-134.

14. Giasuddin M, Sil BK, Alam J, Koike I, Islam MR and Rahman MM (2002). Prevalence of poultry diseases in Bangladesh. Online Journal of Biological Sciences 2 (4): 212-213. 
15. Hofstad MS, Calnek BW, Helmboldt CF, Reid WM and Yoder HW (1978). Coccidiosis. In: Diseases of Poultry. $7^{\text {th }}$ edn. Ed. B. W. Calnek. Iowa State University Press, Ames, Iowa, USA. pp. 784-805.

16. Hosmer DW and Lemeshow S (1989). Applied logistic regression. Jhon Wiley and Sons, New York. pp. 25-58.

17. Islam MR, Das BC, Hossain K, Lucky NS and Mostafa MG (2003). A study on the occurrence of poultry diseases in Sylhet region of Bangladesh. International Journal of Poultry Science. 2(5): 354-356.

18. Islam MR, Khan MAHNA, Das PM and Bari ASM (1988). Poultry diseases diagnosed at necropsy in 1997 and 1998 on the Department of Pathology of Bangladesh Agricultural University, Mymensingh. Proceedings of the $5^{\text {th }}$ BSVER Annual Scientific Conference, December 3-4, 1998, Bangladesh Agricultural University, Mymensingh.

19. Kutubuddin M (1973). Pathological investigation on the causes of mortality of poultry birds in Bangladesh Agricultural University Poultry Farm. MS thesis. Submitted to the Faculty of Veterinary Science.

20. Muhairwa AP, Msoffe PL, Ramadhani S, Mollel EL, Mtambo MMA. and Kassuku AA (2007). Prevalence of gastrointestinal helminthes in free-range ducks in Morogoro Municipality, Tanzania. Livestock research for rural development. 19(4).

21. Mushi EZ, Binta MG, Chabo RG, Mogametsi MM and Samakabadi EK (2008). Escherichia coli infections in chicken broilers in Sebele, Gaborne, Botswana. Research Journal of Poultry Science. 2(2): 29-34

22. Nasrin MM (2004). Parasites of pigeon (Columba livia) in Mymensingh district, Bangladesh. M. S. thesis. Submitted to the Department of Parasitology, Faculty of Veterinary Science, Bangladesh Agricultural University, Mymensingh.

23. Nicole L, Musangu N, Gabriel B and Joseph R (2000). Retrospective study of Escherichia coli in broilers subjected to postmortem examination and antibiotic resistance of isolates in Trinidad. Avian Diseases. 44: 155- 160.

24. Pandey VS and Jiang J (1992). Observation of helminth parasites of domestic fowls in Zimbabwe. Zimbabwe Veterinary Journal. 20: 15-17.

25. Paul DC, Haque MF, Abedin MZ and Akter MS (1990). Participation of women in poultry husbandry in rural Bangladesh. Paper presented in the $10^{\text {th }}$ AFSRE symposium held at Mat Chining University, USA during 14-17 October, 1990.

26. Rabbi AKMA, Islam A, Majumder S, Anisuzzaman and Rahman MH (2006). Gastrointestinal helminthes infection in different types of poultry. Bangladesh Journal of Veterinary Medicine. 4(1): 13-18.

27. Rimler RB and Glisson JR (1997). Fowl cholera. In: Diseases of Poultry. $10^{\text {th }}$ edn. Ed. B. W. Calnek. Iowa State University Press, Ames, Iowa, USA. PP. 143.

28. Stayer PA, Pote LM and Keirs RW (1995). A comparison of Eimeria oocysts isolated from litter and fecal samples of broiler houses at two farms with different management schemes during on grow out. USA Poultry Journal. 74(1): 26-32

29. Talha AFSM, Hossain MM, Chowdhury EH, Bari ASM, Islam MR and Das PM (2001). Poultry diseases occurring in Mymensingh district of Bangladesh. The Bangladesh Veterinarian. 18: 20-23.

30. Thitisak W (1992). Untersuchungen über die Häufigkeit und Ursachen der Abgänge bei der kleinbäuerlichen Geflügelhaltung in Nordosten Thailands. Unpublished Dr Med. Vet., Tierärtzlichen Hochschule Hannover, Hannover. $84 \mathrm{p}$.

31. Tran TP, Nguyen TT, Akiba M, Ogasawara N, Shinoda D, Okatani TA and Hayashidani H (2004). Prevalence of Salmonella spp. in pigs, chickens and ducks in Mekong Delta, Vietnam. Journal of Veterinary Medical Science. 66: 10111014.

32. Zar JH (2002). Biostatistical Anslysis. $4^{\text {th }}$ edn. Pearson Education (Singapore) Pte. Ltd. pp. 555-557. 